\title{
Rarest Eagle Owl in Trouble
}

\author{
G. B. White
}

The nduk or Vosseler's eagle owl Bubo vosseleri is known from only eight specimens in one area of Tanzania. No ornithologist has ever certainly seen this owl in the wild, and nothing is known about its status. But the author, who lived in the area for several years, fears that numbers must be small and are bound to be affected by the steady destruction of the forest that is going on.

The nduk or Vosseler's eagle owl Bubo vosseleri, was described in 1908 from a specimen sent to the Berlin Museum from Amani, 3000 feet up in the heavily forested eastern Usambara Mountains of what is now Tanzania. In 1906 an immature specimen had also reached Berlin from the same locality, but precise collection data are not available for either skin (Moreau, 1964). No further owls were reported for 55 years, despite the fact that Dr Reg Moreau, one of Africa's leading ornithologists, resided in the type locality at Amani from 1928 to 1946 . However, the species was re-discovered there in 1962 when a fledgling was found in the forest less than a mile from Amani, at Nderema. That bird reached the London Zoo in good health and survived until September 1971, when it died suddenly.

I can now report that five more immature nduk eagle owls have been found in recent years in places near Amani where the forest floor has been cleared for cultivation of caradamom spices. The first three of these were each brought by local people to the East African Malaria Research Institute at Amani within a few days of Christmas in 1969,1970 and 1971 respectively. The other two, as reported to me by Dr J. Raybould, were found in January 1972 and 1973 respectively; all were flightless downy youngsters. My wife and I kept the 1969 bird as a house-pet, feeding it exclusively on rats and raw beef wrapped in cotton wool, until we left Amani in September 1971; it is now in the London Zoo in the aviary vacated by its predecessor. Unfortunately, the 1970 and 1971 birds were not treated well enough to survive; the 1972 bird died after two weeks, but the 1973 one survives in the care of Dr Theo Goosens, a Dutch medical officer living at Amani.

No pilgrimages to the Usambara forests by bird-watchers seeking this rarest of eagle owls have ever yet been rewarded. Moreau wrote that he may have glimpsed one fly across a road in daylight in 1931, and he probably observed a large nestling peering from a high nesthole on December 20,1930. That date correlates well with the recent evidence for nest-leaving at the end of December (although the 1962 bird was found immature in April). No other sightings have been reported first-hand, although Moreau quotes a probable thirdhand record of one on the wing by day in the early $60 \mathrm{~s}$.

Our pet specimen regularly uttered two quite different subdued calls: one was a gargling chuckle which it would perform in greeting and conversation with us, often puffing out the feathers as it did so; 


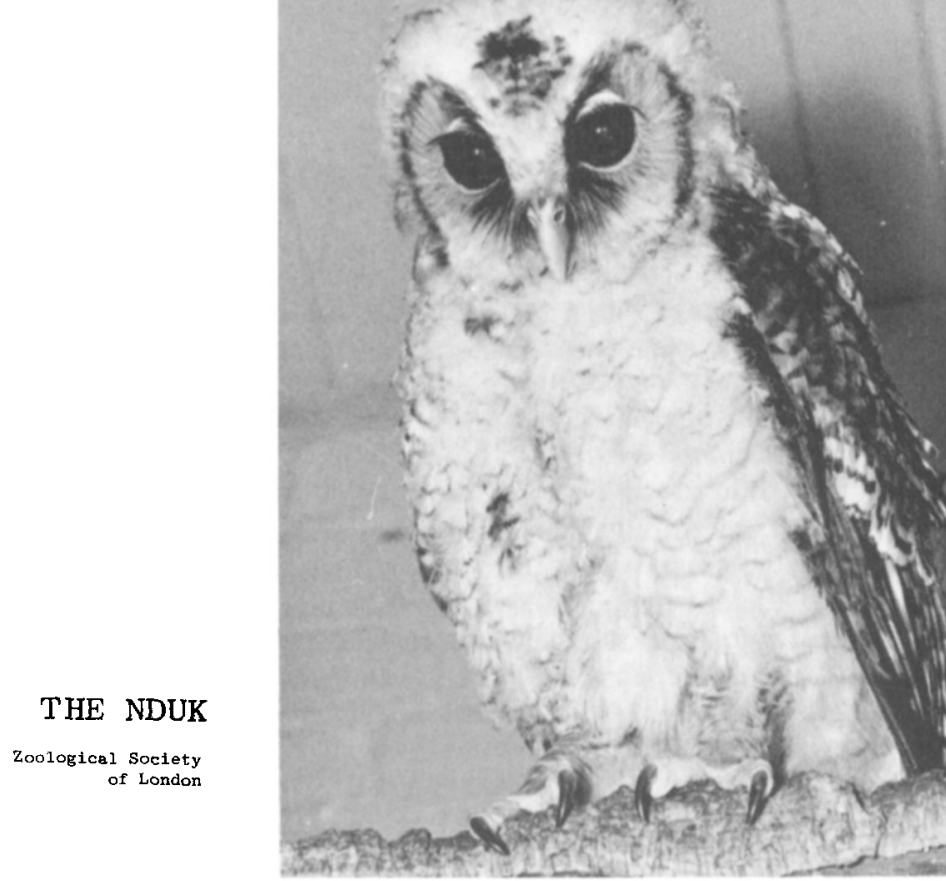

the other, characteristically made at night, consisted of a series of three double syllables resembling the up-down notes of a saw drawn sharply through plywood. At Bwamba in Uganda I have heard a similar but significantly different owl-call, with a tri-syllabic third component, from a bird that I feel must have been the closely related Fraser's eagle owl Bubo poensis. This possible call distinction is interesting in view of the tendency of some authorities to regard $B$. vosseleri as a geographical subspecies of $B$. poensis.

Often a wild owl, never more than one at a time, would visit our Amani garden late at night and exchange calls with our tame bird caged on the open veranda. Both birds performed the thrice-repeated double syllable identically, and in turn, at intervals of about 30 seconds to 3 minutes. The wild owl came at all times of night, on and off for a couple of years, sometimes coming for several consecutive days but sometimes not for many weeks.

During over four years' residence at Amani we never heard or saw any of these owls in the dense canopy forest that covers perhaps thirty square miles of the eastern Usambaras. The failure of so many enthusiastic visitors and long-term residents alike ever to see the eagle owls in the wild indicates their extreme unobtrusiveness despite their rather conspicuous pale plumage. This is additionally surprising because they are alert and often active by day in captivity-ours was most energetic around dusk and dawn. A reliable friend who had lived for years at Ngambo near Amani, and had often heard these owls, told me that in 1970 he heard one calling several times in his garden at Ambangulu estate in the western Usambara Mountains. This suggests that they may range throughout the Usambaras, which cover over 1000 square miles, and if so they may be less in danger then the current destruction rate of their forest homeland leads one to fear. Even so, there can be little 
doubt that the thick stands of valuable indigenous timber will be exhausted well within this decade, with consequent drastic reduction in the availability of nesting-sites in old tree trunks. Small areas of forest reserve do exist which may provide suitable hunting grounds, but with comparatively few suitably old trees for nesting. Competition for nestholes is probably exacerbated by rivalry with silvery-cheeked hornbills Bycanistes brevis-spectacular, noisy and conspicuous birds throughout the Usambaras, which may at some seasons occur in flocks of up to 300 . Already they seem to be suffering a serious shortage of nesting-sites.

Mercifully the introduction of cardomom plantations does require the preservation of some large shade trees. The fact that regenerative undergrowth has now been cleared from most of the forest around Amani is doubtless the reason that fledgling owls have been found more frequently by peasant farmers in the last few years and brought for sale to sympathetic research staff at the nearby Institute. By tactful arrangements with senior staff of the Institute it should be possible to ensure that any owl chicks found in the future are passed on safely to appropriate zoos specialising in breeding such birds, without encouraging nest-raiding or the wanton collection of healthy young owls still in the care of their parents. The long-term prospects for this only known population of the nduk eagle owl depend necessarily on how well the birds can withstand the conditions of large-scale cardamom and tea cultivation, and the extensive teak afforestation programme now under way near Amani.

Peter Olney, Curator of Birds to the Zoological Society of London, writes about the plumage of $B$. vosseleri:

Moreau (1964) described and compared with the closely related $B$. poensis the plumage of a $B$. vosseleri specimen then living at the Zoo. This specimen was apparently $1 \frac{1}{2}$ years old and he assumed that the plumage was similar, if not the same, as for an adult. The specimen now at the Zoo, presented by Dr and Mrs White in December, 1971, is about $4 \frac{1}{2}$ years old and broadly the plumage is the same as that described by Moreau. This confirms that the main significant difference shown by vosseleri is that the blotching on the breast is much more conspicuous and the bars on the underparts are more widely spread than in poensis. A difference which has become more apparent as the present zoo bird grew older is that the border of the facial disc is distinctly wider and darker in vosseleri than in poensis, a distinction not mentioned by Moreau and not apparent in a younger bird. Our living specimen also confirms Moreau's statement that the white shoulder patch which Reichenow (1908) included as a characteristic difference between the two species disappears as the adult plumage is assumed. The type specimen on which the original description was based is then obviously a sub-adult.

References

MOREAU, R. E. 1964. The re-discovery of an African Owl, Bubo vosseleri. B.O.C. Bull. $84: 47-52$.

REICHENOW, 1908.J. Orn. 58: 139. 